\title{
PERANAN KOMPOS PELEPAH KELAPA SAWIT DENGAN BIOAKTIVATOR MOL POME TERHADAP PENINGKATAN SIFAT BIOLOGI TANAH SUB OPTIMAL
}

\section{(The Role of Oil Palm Midrib Compost With Mol Pome Bioactivator Towards Enhancement of Suboptimal Soil Biological Properties)}

\author{
Zainudin $^{1}$, dan Roro Kesumaningwati ${ }^{2}$ \\ ${ }^{1}$ Fakultas Pertanian Universitas Widyagama Mahakam Samarinda \\ ${ }^{2}$ Fakultas Pertanian Universitas Mulawarman \\ Email : zainudin@uwgm.ac.iddan Rorokesuma99@gmail.com
}

Article Submitted: 01-03-2020

Article Accepted: 28-09-2020

\begin{abstract}
Sub-optimal land is a lot of land that are spread in East Kalimantan. Sub-optimal land conditions that have low biological properties is one of the limiting factors in sub-optimal land use for agricultural cultivation. Available suboptimal lands include Ultisol soil types, Imperata grasslands, and ex-coal mining land. This sub-optimal land requires the identification of biological characteristics before determining how to manage it. The research objective is the identification of microfauna including the total population of microorganisms and the identification of bacteria and fungi. This research will be carried out for 1 (one) year. This research includes the following steps: Making a solution of POME microorganisms takes 14 days, making oil palm frond compost with POME mole bio activator takes about 1 (one) month, Incubation of sub optimal ex-soil applied to compost requires 2 weeks, and analysis of the total population of soil microorganisms and identification of bacteria and fungi. The results showed that: 1. The fungi population in sub-optimal land has increased with the addition of oil palm frond compost with POME bio activator, 2. There are six genera of fungi namely Trichoderma, Penicillium, Aspergillus, Clamidiospora, Mucor, and Aerobasidium, 3. The bacteria population in sub-optimal land has not increased with the addition of oil palm frond compost with a POME bio activator.
\end{abstract}

Keywords: sub-optimal land, bio activator, oil palm frond compost

\section{PENDAHULUAN}

Lahan sub optimal merupakan lahan yang banyak tersebar di Kalimantan Timur.Perubahan yang terjadi tidak hanya berupa perubahan fisik tetapi juga perubahan secara kimia dan biologi.Perubahan secara biologi menyebabkan hilangnya biodiversitas tanah dibandingkan denganekosistem yang masih alami sehingga berpengaruh terhadap kesuburan biologi tanah.
Biodiversitas tanah merujukpada semua organismeyang hidup di dalam tanah yang kemudianterbagi kedalam makro, meso maupun mikro fauna dan kelompokmikroorganisme yaitu bakteri, jamur, protozoa dan alga.Tanah memilikikeragaman biologi yang sangat tinggi dan organisme tanahmerupakan faktor kunci yang akan dipengaruhi oleh tanahsebagai habitatnya. Organisme tanah pada suatu ekosistem memiliki peranan 
penting dalammempertahankan kemampuan tanah secara terus menerusdengan menjaga fungsi ekologi tanah melalui hubungan timbal balik dengan tanaman (Irawati, dkk., 2016).

Organisme tanah merupakan salah satu indikator kesuburan tanah karena semakin banyak organisme tanah maka tanah tersebut dalam kondisi baik Organisme tanah mempunyai peranan tertentu dalam ekosistem, diantaranya adalah sebagai dekomposer dan dalampenyediaan unsur hara dalam tanah serta berperan dalam memperbaiki sifat fisik tanah. Organisme tanah dapat digunakan sebagai bioindikator kesuburan tanah karena memiliki respon positif terhadap pengolahan tanah, berperan dalam dekomposisi dan siklus hara, mengikatlogam berat dan menekan organisme patogen (Lestari, N. A., 2019).

Penggunaan pupuk organik dengan menggunakan bioaktivator larutan mikroorganisme POME diharapkan dapat meningkatkan sifat biologi tanah, oleh karena itu penelitian ini sangat penting dilakukan untuk mengetahui populasi mikroorganisme dalam meningkatkan sifat biologi tanah sub optimal.

\section{METODE PENELITIAN}

Penelitian ini rencananya dilakukan selama 1 (satu) tahun, mulai Bulan Maret 2019 hingga November 2019. Penelitian dilakukan di Fakultas Pertanian Universitas Widya Gama Mahakam, Samarinda. Laboratorium yang digunakan adalah Laboratorium hama penyakit tumbuhan Fakultas Pertanian Universitas Mulawarman.

\section{Pembuatan larutan mikroorganisme POME}

Bahan Pembuatan mol :Toples ukuran 25 liter, 5 liter POME, Gula merah 1 kg, Air kelapa 5 liter, Air cucian beras 5 liter.

Cara pembuatan mol :

Campurkan larutan POME, gula merah yang lebih dulu dicairkan, tambahkan 5 liter air kelapa, 5 liter air cucian beras dan aduk hingga rata. Tutup rapat dengan selang terpasang pada botol air mineral bekas terisi air dan dilakukan fermentasikan selama 14 hari

\section{Pembuatan kompos pelepah kelapa sawit}

Kompos dibuat dengan cara memotong-motong pelepah kelapa sawit dengan ukuran 5-10 cm. Encerkan bioaktivator dengan melarutkan $500 \mathrm{ml}$ biang larutan mol dalam 1 liter air. Campuran larutan tersebut disiram secara perlahan dan merata ke dalam potongan pelepah kelapa sawit hingga kandungan air di adonan mencapai $30-40 \%$, tandanya, bila campuran dikepal, air tidak keluar dan bila kepalan dibuka, adonan tidak buyar.

Adonan yang telah dicampur tersebut diletakkan di atas karung, atur tinggi tumpukan setinggi $20-30 \mathrm{~cm}$ dengan suhu tumpukan dipertahankan antara $40-50^{\circ} \mathrm{C}$. Bila suhu tumpukan lebih dari $50^{\circ} \mathrm{C}$ dapat diturunkan dengan cara membolak-balik (suhu yang tinggi dapat mengakibatkan kompos menjadi rusak karena terjadi proses pembusukan). Setelah \pm 1 bulan kompos telah selesai terfermentasi dan siap digunakan sebagai pupuk organik.

\section{Inkubasi tanah sub optimal (tanah bekas tambang batubara)}

Penelitian ini dilakukan secara deskriptif dengan 4 perlakuan dan 5 ulangan. Adapun macam perlakuan dalam penelitian ini dapat diuraikan sebagai berikut:

f0 : Tanah tanpa kompos

f1 : Tanah $5 \mathrm{~kg}+100 \mathrm{~g}$ kompos

f2 : Tanah $5 \mathrm{~kg}+200 \mathrm{~g}$ kompos

$\mathrm{f} 3$ : Tanah $5 \mathrm{~kg}+300 \mathrm{~g}$ kompos

Inkubasi tanah dilakukan dengan mencampurkan tanah yang telah dibersihkan dari kotoran dengan kompos sesuai dengan perlakuan.Inkubasikan tanah selama 1 bulan. Perawatan dilakukan dengan cara menyiram tanah dengan air agar kelembaban bahan selalu terjaga dan membersihkan bila terdapat kotoran-kotoran. Pengambilan data tanah setelah inkubasi dilakukan dengan 
mengambil sampel tanah secara komposit pada setiap ulangan dengan perlakuan yang sama untuk keperluan analisis mikrobiologi.

\section{HASIL DAN PEMBAHASAN}

Mikroba berguna (effective microorganism) sebagai komponen habitat alam mempunyai peran dan fungsi penting dalam mendukung terlaksananya pertanian ramah lingkungan melalui berbagai proses, seperti dekomposisi bahan organik, mineralisasi senyawa organik, fiksasi hara, pelarut hara, nitrifikasi dan denitrifikasi. Mikroba diposisikan sebagai produsen hara, tanah dianggap sebagai media biosintesis, dan hasil kerja mikroba dianggap sebagai pensuplai utama kebutuhan hara bagi tanaman.Semakin tinggi populasi mikroba tanah semakin tinggi aktivitas biokimia dalam tanah dan semakin tinggi indeks kualitas tanah. Populasi mikroba tanah yang tidak bersifat patogenik juga dianggap sebagai salah satu indikator teknologi pertanian ramah lingkungan (Saraswati, dkk., 2008).

\section{Hasil analisis populasi jamur}

Berdasarkan tabel 1 diperoleh bahwa total populasi jamur mengalami peningkatan jika dibandingkan dengan kontrol (f0) pada semua perlakuan penggunaan kompos pelepah kelapa sawit dengan bioaktivator mol POME. Total populasi jamur tertinggi terdapat pada perlakuan $\mathrm{f} 4$ dengan nilai 20,6 x $10^{4} \mathrm{Cfu} / \mathrm{g}$, hal ini membuktikan bahwa penambahan bahan organik berupa kompos pelepah kelapa sawit memacu aktivitas mikroorganisme yang ditandai oleh meningkatnya total populasi jamur pada tanah inkubasi.

Tabel 1. Total populasi jamur pada tanah inkubasi dengan kompos sampah pasar

\begin{tabular}{ccc}
\hline No & Kode Sampel & Total populasi (Cfu/g) \\
\hline 1 & f0 & $5,5 \times 10^{4}$ \\
2 & f1 & $13,6 \times 10^{4}$ \\
3 & f2 & $11,1 \times 10^{4}$ \\
4 & f3 & $20,6 \times 10^{4}$ \\
\hline
\end{tabular}

Sumber : Hasil analisis di laboratorium Hama dan Penyakit Tumbuhan Unmul (2019)

Total populasi mikroorganisme dapat digunakan untuk menduga produktivitas lahan khususnya lahan pertanian, hal ini disebabkanoleh mikroorganisme tanah yang bersifat sebagai dekomposer. Tanah yang subur ditunjukkan denganjumlah populasi mikroorganisme lebih dari 100 juta (Yusmar, M., dkk., 2019). Total populasi dan keragaman mikroba dari suatuekosistem perlu diketahui dan dapat digunakan sebagaisalah satu indikator kesuburan tanah, sehingga penurunantotal dan keragaman mikroba tanah dapat digunakansebagai indikasi awal dari gangguan yang terjadi padakualitas ekosistem dan dapat dimanfaatkan sebagailandasan untuk pengembangan teknologi pertanian (Pratiwi, E., 2018). Ditambahkan oleh Purwaningsih (2005) Tingginya jumlah mikroorganisme merupakan salah satu ciri tingginya tingkat kesuburan tanah, karena mikroba merupakan perombakbahan organikmenghasilkan unsur hara sehingga dapat tersedia bagi tanaman. 
Tabel 2. Populasi jamur pada tanah inkubasi dengan kompos sampah pasar

\begin{tabular}{|c|c|c|c|}
\hline No & Kode Sampel & Populasi jamur (Cfu/g) & Identifikasi jamur \\
\hline 1 & f0 & $\begin{array}{l}1,6 \times 10^{4} \\
1,5 \times 10^{4} \\
2,4 \times 10^{4}\end{array}$ & $\begin{array}{l}\text { Trichoderma } \\
\text { Aspergillus } \\
\text { Aerobasidium }\end{array}$ \\
\hline 2 & f1 & $\begin{array}{l}1,2 \times 10^{4} \\
1,8 \times 10^{4} \\
1,4 \times 10^{4} \\
6 \times 10^{4} \\
3,2 \times 10^{4}\end{array}$ & $\begin{array}{l}\text { Trichoderma } \\
\text { Penicillium } \\
\text { Aspergillus } \\
\text { Mucor } \\
\text { Aerobasidium }\end{array}$ \\
\hline 3 & $\mathrm{f} 2$ & $\begin{array}{l}1,6 \times 10^{4} \\
4,8 \times 10^{4} \\
1,8 \times 10^{4} \\
2,9 \times 10^{4}\end{array}$ & $\begin{array}{l}\text { Trichoderma } \\
\text { Penicillium } \\
\text { Aspergillus } \\
\text { Aerobasidium }\end{array}$ \\
\hline 4 & f3 & $\begin{array}{c}9 \times 10^{4} \\
1,1 \times 10^{4} \\
1,7 \times 10^{4} \\
3 \times 10^{4} \\
5,8 \times 10^{4}\end{array}$ & $\begin{array}{l}\text { Trichoderma } \\
\text { Penicillium } \\
\text { Aspergillus } \\
\text { Cladosporium } \\
\text { Aerobasidium }\end{array}$ \\
\hline
\end{tabular}

Sumber : Hasil analisis di laboratorium Hama dan Penyakit Tumbuhan Unmul (2019)

Berdasarkan tabel 2 diketahui bahwa terdapat 6 (enam) genus jamur yaitu Trichoderma, Penicillium, Aspergillus, Cladosporium, Mucor dan Aerobasidium. Perlakuan f1, f2, dan f3 memiliki keragaman jenis jamur yang lebih bervariasi dibandingkan dengan f0 (kontrol) yang hanya memiliki 3 (tiga) genus jamur. Menurut Wulandari, dkk (2013), Perbedaan lokasi dan rizosfer menyebabkan perbedaan keanekaragaman spesies dan populasi cendawan. Tekstur tanah yang didominasi oleh fraksi lempung (clay) biasanya mengandung jumlah mikroorganismenya lebih sedikit dibandingkan kondisi tanah dengan tekstur berpasir.

Perlakuan f1, f2, dan f3 menunjukkan bahwa terdapat genus Mucor dan Penicillium yang tidak ada pada perlakuan kontrol, hal ini menunjukkan perlakuan pemberian kompos pelepah kelapa sawit sebagai sumber bahan organik dapat meningkatkan ketersediaan fosfor. Ditambahkan oleh (Siswanto, D., 2006), adanya genus Penicillium dan Mucor menunjukkan bahwa tanah tersebut banyak mengandung fosfor karena kedua genus jamur tersebut berperan dalam degradasi fosfat.

Penicillium sp.,Trichoderma sp.dan Aspergillus sp. merupakan jenisjamur yang kebanyakan dapat tumbuh pada mediayang mengandung lignin.Bahkan jamur Penicillium sp.dapat menyebabkan peningkatan pertumbuhan tanaman karena kemampuan Penicillium untuk menyediakan unsurhara bagi tanaman.Ketersediaan hara tanah melalui mekanisme mendegradasi sisa-sisa bahan organik oleh jamur Penicillium.Genus jamur yang terdapat pada semua perlakuan adalah Aspergillusyang memilikikemampuan cukup besardalam mendegradasi senyawa lignin.Jamur Aspergillus banyak dimanfaatkan untukdekomposisi lignin maupunsebagai mikroorganisme

penyuburantanah.Aspergillus menghasilkan enzim yang dapat digunakan untuk mengurai lignin menjadi senyawakarbon sederhana yang dimanfaatkan oleh mikrobatanah 
sebagai sumber energi(Valencia, 2017).Aspergillus dan Penicilium berperan di dalam penyediaan unsur hara yaitu merupakan mikroba pelarut fosfat $(\mathrm{P})$ dan kalium (K).Mikroba yang berkemampuan tinggi melarutkan $\mathrm{P}$, umumnya juga berkemampuan tinggi dalam melarutkan $\mathrm{K}$.

Jamur Trichoderma juga merupakan jamur yang terdapat pada semua perlakuan termasuk kontrol.Keberadaan jamur Trichoderma memiliki dampak positif bagi tanah karena Trichoderma bersifat mengurangi patogen tanah karena adanya senyawa yang bersifat toksin bagi patogen (Widyati, E. 2013). Trichoderma memiliki kemampuan untuk meningkatkan

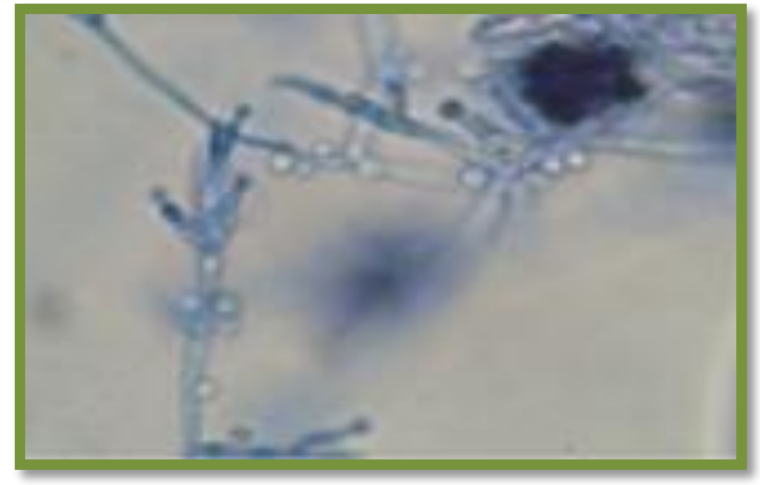

Gambar 1. Jamur Trichoderma

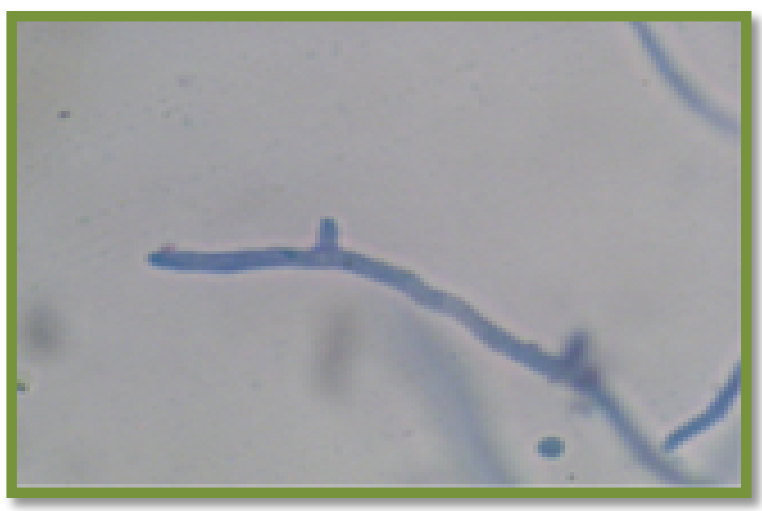

Gambar 3. Jamur Aerobasidium pertumbuhan tanaman karena meningkatkan kelarutan unsur hara tanah yang memiliki peran penting dalam pertumbuhan tanaman (Kesumaningwati, dkk., 2014).

Jamur Cladosporium hanya ditemukan pada perlakuan f3,menurut Wulandari, dkk (2013),Cladosporium berperan terhadap hama patogen sekunder pada semuatanaman. Spesies ini telah diisolasi daritanah, udara, dan bijibijian.Ditambahkan oleh Miranti (2015), Cladosporium termasuk salah satu genus jamur yang dapat menghasilkan enzim selulase sehinggamemiliki kemampuan mendekomposisi kayu.

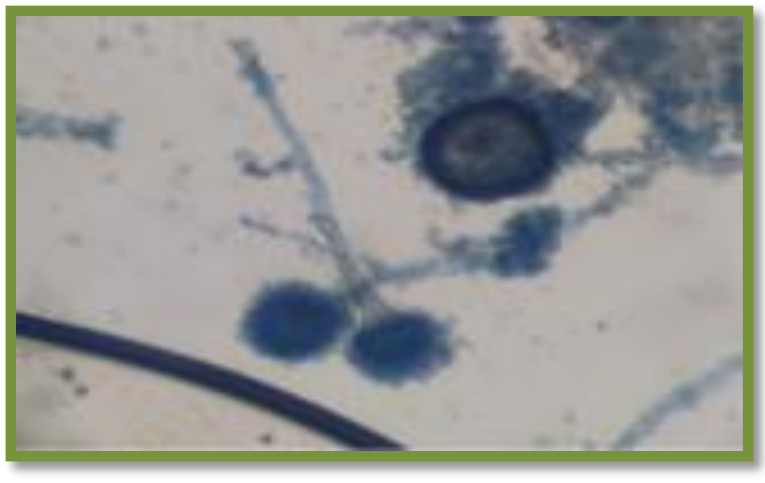

Gambar 2. Jamur Aspergillus

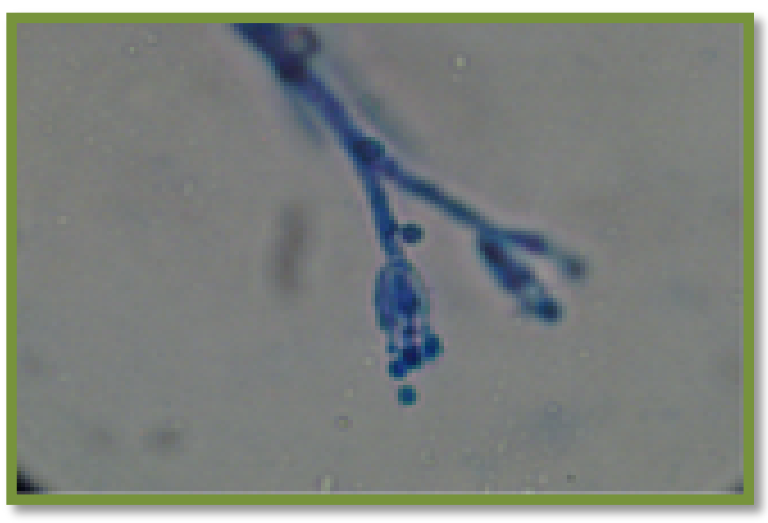

Gambar 4. Jamur Penicillium 


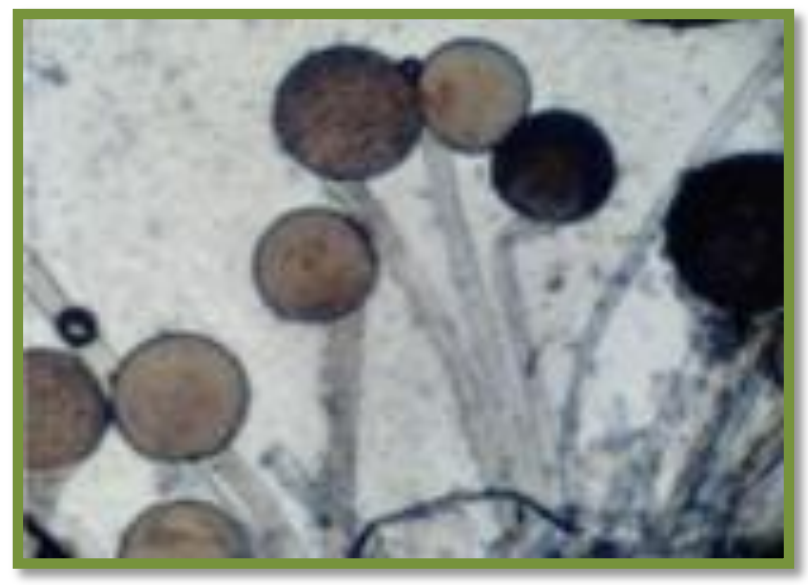

Gambar 5. Jamur Mucor

\section{Hasil Analisis Populasi Bakteri}

Bakteri yang diisolasi dari tanah inkubasi dengan aplikasi kompos pelepah kelapa sawit dengan bioaktivator mol POME adalah bakteriAzotobacteraceae, Basil gram-negatif dan Kokus gram-negatif.

Tabel 3. Populasi bakteri pada tanah inkubasi dengan kompos sampah pasar

\begin{tabular}{|c|c|c|c|}
\hline No & Kode Sampel & $\mathrm{Cfu} / \mathrm{g}$ & Identifikasi Bakteri \\
\hline \multirow[t]{3}{*}{1} & f0 & $1,9 \times 10^{5}$ & Basil gram (-) \\
\hline & & & $\begin{array}{c}\text { Azotobacteraceae } \\
\text { Kokus gram (-) }\end{array}$ \\
\hline & & & Azotobacteraceae \\
\hline \multirow[t]{2}{*}{2} & f1 & $1,7 \times 10^{5}$ & Kokus gram (-) \\
\hline & & & Azotobacteraceae \\
\hline \multirow[t]{2}{*}{3} & f2 & $1,9 \times 10^{5}$ & Kokus gram (-) \\
\hline & & & Azotobacteraceae \\
\hline \multirow[t]{2}{*}{4} & f3 & $1,7 \times 10^{5}$ & Kokus gram (-) \\
\hline & & & Azotobacteraceae \\
\hline
\end{tabular}

Sumber : Hasil analisis di laboratorium Hama dan Penyakit Tumbuhan Unmul 2019

Berdasarkan tabel 3 dapat dilihat bahwa penambahan kompos pelepah kelapa sawit tidak meningkatkan populasi Azotobacteraceae, bahkan pada perlakuan F1 dan F3 mengalami penurunan. Ditambahkan oleh Hindersah, R., (2019), penurunan populasi Azotobacteraceae pada tanah bisa terjadi karena adanya persaingan dengan mikroorganisme lain. Pendapat Danapriatna, N., (2016) mengatakan bahwa penurunan populasi Azotobacteraceae terjadi karena ketidaksesuaian dengan tempat hidupnya. Azotobacteraceae mendapatkan energi lebih baik pada tanah dengan kadar oksigen rendah seperti pada lahan basahdan lahan tergenang.

Ditambahkan oleh Hindersah, R (2018), penambahan bahan organik tidak memberi pengaruh pada populasi Azotobacter pada tanah bekas tambang, karena tanah bekas tambang mengandung $\mathrm{N}$ rendah sehingga mengakibatkan $\mathrm{C} / \mathrm{N}$ tinggi, hal ini menyebabkan aktivitas mikroba perlu waktu lebih lama untuk mendekomposisi bahan organik. 


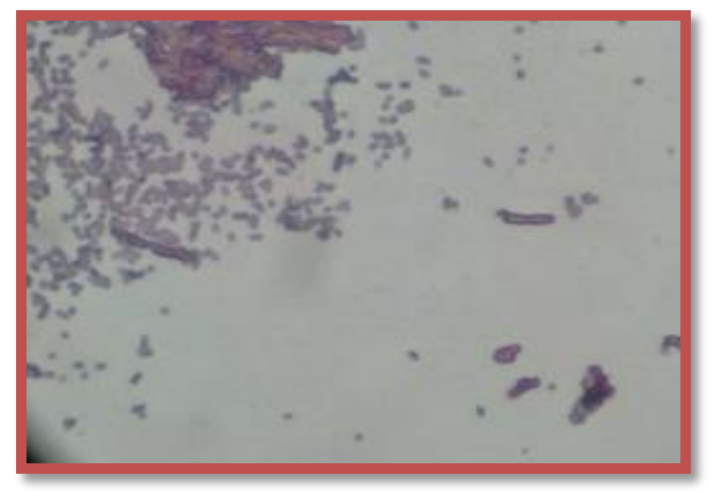

Gambar 6. BakteriAzotobacteraceae

Keberadaan Azotobacteraceae ini sangat penting bagi kesuburan tanah karena dapat meningkatkan unsur hara tanah terutama nitrogen. Menurut Kesumaningwati (2018), bakteri Azotobacteraceae meningkatkan nitrogen tanah karena merupakan bakteri penambat nitrogen.

\section{KESIMPULAN}

1. Populasi jamur pada lahan sub optimal mengalami peningkatan dengan penambahan kompos pelepah kelapa sawit dengan bioaktivator POME

2. Terdapat enam genus jamur yaitu Trichoderma, Penicillium, Aspergillus, Clamidiospora, Mucor dan Aerobasidium

3. Populasi bakteri Azotobacteraceae pada lahan sub optimal tidak mengalami peningkatan dengan penambahan kompos pelepah kelapa sawit dengan bioaktivator POME

\section{UCAPAN TERIMA KASIH}

Kepada Universitas Widya Gama Mahakam Samarinda yang telah memberikan dana penelitian melalui dana DIPA Unvirsitas Tahun 2019.

\section{DAFTAR PUSTAKA}

Bartram, H., and A. Perkins 2003. The biodiversity benefits of organic
farming.Proceedings of the OECD Workshop on organic Agriculture, September 2002.Paris, OECD. p. 7793

Cherni, A.E., D. Trabelsi., S. Chebil., F. Barhoumi., I. D. R. Llorente., and. Zribi. 2015. Effect Of Glyphosate On Enzymatic Activities, RhizobiaceaeAnd Total Bacterial Communities In An AgriculturalTunisian SoiL. Water Air Soil Pollut 11270 : 145-226

Danapriatna, N. 2016.Penjaringan Azotobacter Sp Dan Azospirillum Sp Dari Ekosistem Lahan Sawah Sebagai Sumber Isolat Pupuk Hayati Penambat Nitrogen. Jurnal Agrotek Indonesia 1 (2) : 115 - 122 (2016) ISSN : 2477-8494

Departemen Pertambangan dan Energi Direktorat jenderal Pertambangan UMUM. 1996. Pedoman Reklamasi Lahan Bekas Tambang. Jakarta

Desai, S., G. P. Kumar., L. D. Amalraj., D. J. Bagyaraj., and R. Ashwin.2016.Exploiting PGPR And Amf Biodiversity For Plant Health Management. Springer India. Microbial Inoculants in Sustainable Agricultural Productivity pp 145-160 
Gurikar C., Naik M.K., Sreenivasa M.Y. 2016.Azotobacter: PGPR Activities with Special Reference to Effect of Pesticides and Biodegradation. In: Singh D., Singh H., Prabha R. (eds) Microbial Inoculants in Sustainable Agricultural Productivity. Springer, New Delhi. Microbial Inoculants in Sustainable Agricultural Productivity pp 229-244

Hanafiah, K. A. 2005. Dasar-dasar Ilmu Tanah.Raja Grafindo Persada. Jakarta

Hardjowigeno, S. 2003. Ilmu tanah. Akademika Pressindo. Jakarta

Hindersah, R., N. Rostini., A. Harsono., dan A. M. Kalay. 2019. PeranEksopolisakaridaAzotobacterdan BahanOrganikuntukMeningkatkanNod ulasidanBiomassaKedelaipadaDuaOrd oTanah.J. Agron. Indonesia, Agustus, 47(2):156-162

Hindersah, R., Z. Handyman., F.N. Indriani., P.Suryatmana, and N. Nurlaeny.2018. Azotobacter population, soil nitrogen and groundnut growth inmercury contaminated tailing inoculated with Azotobacter. Journal Of Degraded And Mining Lands ManagementVol 5, No 3 ,

1274DOI:10.15243/jdmlm.2018.053.1 269

Husnaeni, F., dan M. R. Setiawati. 2018.

Pengaruh Pupuk Hayati Dan

Anorganik Terhadap

PopulasiAzotobacter, Kandungan N, Dan Hasil Pakcoy Pada Sistem Nutrient Film Technique. Jurnal Biodjati, 3 (1) 2018

Indriani, Y. H. 2003. Membuat Kompos Secara Kilat. Penebar Swadaya. Jakarta
Irawati, A., R. Widyastuti, A. Sutandi dan K. Idris. 2016. Biodiversitas dan Sifat Kimia Tanah pada Ekosistem Lada dan Ubi Kayu di Lampung Timur. Jurnal Tanah dan Iklim Vol. 40 No. 1 2016:51-59

Irvan, B. Trisakti, M. Vincent, dan Y. Tandean. Pengolahan Lanjut Limbah Cair Kelapa Sawit Secara AerobikMenggunakan Effective Microorganism Guna Mengurangi Nilai TSS. Jurnal Teknik Kimia USU. Volume 1 No 2 (2012). Hal 27-30

Iskandar, Suwardi, dan Suryaningtyas. 2012. Reklamasi Lahan-Lahan Bekas Tambang.Beberapa Permasalahan Terkait Sifat-sifat Tanah dan Solusinya. Pusat Studi Reklamasi Tambang. LPPM IPB. Bogor.

Isroi.2009.

http://isroi.wordpress.com/2009/05/14/ pemanfaatan jerami padi sebagai pupuk organik in situ untuk mengurangi penggunaan pupuk kimia dan subsidi pupuk.intan nursiamsciencekarakteristik jerami padi, pengertian jerami padi, produksi jerami padi

Kesumaningwati, R dan N. P. Palupi.2014. Aplikasi Bokashi Tandan Kosong Kelapa Sawit dengan MOL Keong Mas pada Tanah Bekas Tambang Batubara.Proceeding of International Seminar "Towards Sustainable Tropycal Ecosystem Management for Green Economyc Management". Hal 276-289. Samarinda 10-14 September

Kesumaning wati, R dan N. P. Palupi. 2018. Peranan Kompos Sampah Pasar dengan Bioaktivator Mol Dan TrichodermaTerhadap Peningkatan Sifat Biologi Tanah Bekas Tambang Batubara. Jurnal Agrifarm vol 7 no 2 
Kumari, E., A. Sen., VK.Srivastava., R. K. Singh., Y. Singh., B.RMaurya., P. Vijaya., and B. Sarma. 2018. Effect of different potassium solubilising bacteria(KSB) and Trichoderma on soil microbial status of baby corn (Zea mays L.). International Journal of Chemical Studies 6(3): 180-183

LeBlanc, N., L. Kinkel and H. C. Kistler. 2017. Plant diversityand plant identity influence Fusarium communities in soil, Mycologia, 109(1): 128-139

Lestari , N. A., dan A. I. Susanti. Kelimpahan Dan KeanekaragamanOrganisme Tanah Bioindikator Kesuburan Lahan Pertanian DanPembuatan Media Penyuluhan Pertanian. Agriovet Vol 2 no $1 ; 1-16$

Manurung, S.O. and M. Ismunadji. 1988. Morfologi dan Fisiologi Padi. Balitan Pangan Bogor.319 hal.

Machadopasin, T., V. Machadobenassi.,P. Ricardoheinen., A. R. De Limadamasio., Marianacereia., J. Atíliojorge, M. D. L. T. D. Moraespolizeli. 2017. Purification And Functional Properties of A Novel Glucoamylase Activated By Manganese And Lead Produced By Aspergillus Japonicus. International Journal Of Biological Macromolecules. 102 : 779-788

Margaretha.2010. Pemanfaatan Tanah Bekas Tambang Batubara dengan Pupuk Hayati Mikoriza sebagai Media Tanam Jagung Manis. Jurnal Hidrolitan. Vol. $1: 3: 1-10$

Mawazin, Adi Susilo. 2016. Pertumbuhan Tanaman Pulai (Alstonia scholaris) pada Lahan Bekas Tambang Batubara di Kalimantan Timur.Prosiding Seminar Nasional Masyarakat
Biodiversity Indonesia.Vol. 2 nomor 2, Desember 2016.ISSN : 2407-8050. DOI : $1013057 / \mathrm{psnmbi} / \mathrm{m} 020220$.

Miranti, A.K. , I. Rukmi. , A. Suprihadi. 2015. Keanekaragaman Kapang Aspergillus pada Serasah Daun Talok (Muntingia calabura L.) di Kawasan Desa Sukolilo Barat, Kecamatan Labang, Kabupaten Bangkalan, Madura. Seminar Nasional Konservasi dan Pemanfaatan Sumber Daya Alam

Muhibuddin, A., L. Addina., A. L. Abadi, and A. Ahmad. 2011. Biodiversity Of Soil Fungi On Integrated Pest Management Farming System. AGRIVITA VOLUME 33 No. 2 : 111118

Pratiwi, E., T. D. Satwika., dan F. Agus. 2018. Keanekaragaman Mikroba Tanah Gambut di Bawah Hutan dan di BawahPerkebunan Sawit di Provinsi Jambi.Jurnal Tanah dan Iklim Vol. 42 No. 1, Juli: 69-78

Purwasasmita, M. 2009. Pemanfaatan Larutan MOL. http://riefarm.blogspot.com/.Tanggal aksess 2 Juli 2012.

Purwaningsih, Sri. 2005. Isolasi, Enumerasi, dan Karakterisasi Bakteri Rhizobium dari Tanah Kebun Biologi Wamena, Papua. Jurnal Biodiversitas.Vol.6(2)8284.

Rahardjo, P. N. Studi Banding Teknologi PengolahanLimbah Cair Pabrik Kelapa Sawit. Jurnal Teknologi Lingkungan Vol 10 No 1. Hal 9-18

Redaksi Agromedia. 2007. Cara Praktis Membuat Kompos. Agromedia Pustaka. Jakarta

Sahwan, F. S.Kualitas Produk Kompos Dan KarakteristikProses Pengomposan 
Sampah KotaTanpa Pemilahan Awal. Jurnal Teknologi Lingkungan. Volume 11 No 1. Hal 79-85

Santosa, E. 2008.Peranan Mikroorganisme Lokal (MOL) Dalam Budidaya Tanaman Padi Metode System of Rice Intensification (SRI) Workshop Nasional SRI.Direktorat Pengelolaan Lahan dan Air.Direktorat Jenderal Pengelolaan Lahan dan Air.Departemen Pertanian.21 Oktober 2008.Jakarta.

Saraswati, Rasti dan Sumarno.2008. Pemanfaatan Mikroba Penyubur Tanah sebagai Komponen Teknologi Pertanian.Iptek Tanaman Pangan Vol. 3 No. 1

Sinaga, A. E., Subiantoro., dan Fatahillah. 2015. Pengaruh Penggunaan Kompos Pelepah Kelapa Sawit denganBerbagai Mikroorganisme Lokal (MoL) dan Cara Aplikasinyaterhadap Sifat Fisik Tanah dan Produksi Tembakau (Nicotianatabacum L.).Jurnal AIP Volume 3 No. 1' Mei 2015: 11-20

Siswanto, D. 2006. Komunitas Kapang Tanah Di Lahan Kritis Berkapur Das Brantas Pada Musim Kemarau. BioscientiaeVolume 3, Nomor 1, Januari 2006, Halaman 1-14

Soemartono, S. dan B. Haryono. 1972. Bertjotjok Tanam Padi. Kanisius.Yogyakarta.

Syib'li,M.A., A. Muhibuddin And S. Djauhari. 2013. Arbuscular Mycorrhiza Fungi As An Indicator Of Soil Fertility. Agrivita Volume 35 No. 1: 44-53
Valencia, P. V., dan V.I.Meitiniarti. 2017. Isolasi dan karakterisasi jamur ligninolitik sertaPerbandingan kemampuannya dalam biodelignifikasi. Scripta biologica, vol 4 no3.September 2017 hal 171175ttps://doi.org/10.20884/1.sb.2017.4 .3 .449

Widyati, E. 2013.Dinamika Komunitas Mikroba di Rizosfir dan KontribusinyaTerhadap Pertumbuhan Tanaman Hutan.Tekno Hutan TanamanVol. No. 62 Agustus 2013, $55-64$

Widuri, S.A., dan Yassir, I. 2012. Pertumbuhan Lahan (Vitex Pinnata) dengan Perlakuan Asam Humat dan Kompos di Lahan Pasca Tambang Batubara, PT. Sing Lurus Pratama, Kalimantan Timur. Balai Penelitian Teknologi Konservasi Sumber Daya Alam

Wulandari, N.L., M.W. Proborini., dan I. K. Sundra. 2013. Eksplorasi Spasial Cendawan Tanah Pada Sekitar RhizosferTanaman Jambu Mete (Anacardium OccidentaleL.) di Karangasem Dan Buleleng - Bali. Jurnal Simbiosis I (2): 85-101Jurusan Biologi Fmipa Universitas UdayanaSeptember 2013

Yusmar, M., Oksana, R. Saragih, dan Armadi. 2019. Keanekaragaman Mikroorganisme Tanah Pada Beberapa Kemiringan Lahan Perkebunan Kelapa Sawit (Elaeis Guineensis Jacq.) Di Kabupaten Rokan Hulu. Prosiding Seminar Nasional Agroteknologi, Jurusan Agroteknologi Universitas Islam Negeri Sunan Gunung Djati Bandung 
